\title{
Analysis of the Potential for Internationalization of a Medium Enterprise in the Mexican Footwear Sector
}

\author{
María Guadalupe Arredondo-Hidalgo, Diana Del Consuelo Caldera-González \\ Universidad de Guanajuato, Guanajuato, México
}

\begin{abstract}
This research is a longitudinal case study with descriptive scope and mixed methodology: quantitative and qualitative. The aim of this paper is to analyze the potential for internationalization of a medium-sized enterprise (SME) in the footwear sector in the city of Leon Guanajuato, Mexico, in order to identify the feasibility of carrying out the plans of international trade. An analysis of both the industry and the organization was made. SME has an incipient experience for the US market. The results show that the company has potential for internationalization, but insertion into other markets must be gradual, given the nature of the organization, and must be formally planned.
\end{abstract}

Keywords: internationalization, enterprise strategies, SMEs

\section{Introduction}

Footwear manufacturing in Mexico is an important trade and economic activity, generating a chain of highly competitive suppliers. In this sense, there are many companies from small to large that seek to position themselves in new markets such as the international one, however the raid on them is slow, because the risk is often high (Secretaría de Economía, 2015).

The aim of this paper is to analyze the potential for internationalization of a medium-sized company in the footwear sector in the city of Leon Guanajuato, Mexico to identify the feasibility of carrying out the plans of international trade.

In Mexico, these companies are the backbone of the economy. Figures from the National Geography Institute (INEGI) mention that $99.8 \%$ of economic units in the country are MSMEs. The Mexican Ministry of Economy classifies them as micro, small and medium enterprises according to the sector they belong, the number of participants or according to its annual sales. If we talk about MSMEs, we combine the three classifications, whose participants would cap 100 and annual sales of 250 million Mexican pesos. The difficulty lies in trying to understand that this object of study is continually facing great challenges, which make their life cycle very short (Arredondo \& Caldera, 2016).

According to Secretaría de Economía (2015), 70\% of companies in the footwear industry are in the state of Guanajuato. According to the Chamber of the Footwear Industry of the State of Guanajuato (CICEG, 2016) in 2014, eight out of every 100 jobs in the state were generated in this sector, i.e., that is strategic for the development of the state. For this reason, this research is relevant in the sense of offering the Mexican SMEs tools that allow them to take the necessary decisions to materialize as successful international business.

\footnotetext{
María Guadalupe Arredondo-Hidalgo, Full Professor, Department of Business Management, Universidad de Guanajuato. Email: mg.arredondohidalgo@ugto.mx; mg.arredondohidalgo@ugtomx.onmicrosoft.com.

Diana Del Consuelo Caldera-González, Full Professor, Department of Organizational Studies, Universidad de Guanajuato.
} 


\section{Description of the Case Study}

For reasons of confidentiality, pseudonyms will be used to refer to the case study company and the companies involved with them. The company that we denominate as CC plans to venture into the international market. This company is located in the city of Leon, Guanajuato, one of the states that account for more than $70 \%$ of the value of production of footwear in Mexico. In addition to its privileged geographical location, it is a company that uses $100 \%$ domestic inputs for the manufacture of its products; it is expected that with these two advantages, the company can take full advantage to enter the international market.

Founded in March 2013, the company manufactures high-quality cowboy boots and is a subsidiary of an American company called KI, which is $100 \%$ capital abroad, from the United States. It is important to clarify that, because it is a subsidiary, it has no control over customers, so it is only responsible for manufacturing the products and then returning it to its headquarters in the United States.

The company's mission is to create products that boldly form the future of the new West, preserving the spirit of the Old West. Its vision describes as being a successful company in sales and positioning their products nationally and internationally in a period of 10 years. The values that characterize CC revolve around adventure (for the type of product manufactured), customers (for cutting edge design), the products (quality offered), and the company itself (the responsibility inward and outside).

Regarding its organizational structure, it is considered a medium-sized company since it has on average 37 workers in its productive plant. It is administratively divided into the departments of accounting, human resources, foreign trade, design, production, purchasing and maintenance. It has a plant for the production of $30 \times 50$ meters, with 2,000 $\mathrm{m}^{2}$ building space which are distributed among the seven departments. Recently, KI asked the company SO (which manufactures hats and belts style "Old West") for a license that permits the use of the SO brand, to apply it in products that currently, the company CC manufactures. This means that the company is committed to production of cowboy boots mainly for the US market. Since its foundation to date, different objectives have guided the CC company and after three years of operation, we have identified several areas of opportunity that can be exploited.

Table 1

Analysis of Critical Business Success Factors

\begin{tabular}{|l|l|}
\hline Objectives & Components of success factors \\
\hline Place the product as one of the best in \\
Mexico & $\begin{array}{l}\text { Design and product quality } \\
\text { Appropriate brand image } \\
\text { Stability of the company in the market } \\
\text { Comfort and durability footwear } \\
\text { Competitive prices } \\
\text { Business link with government associations } \\
\text { Participation in trade fairs }\end{array}$ \\
\hline Being a company with a high export & $\begin{array}{l}\text { Competitive geographical position } \\
\text { Accessible distribution channels } \\
\text { Using the trademark Stetson, recognized in the market } \\
\text { Applied benefits of free trade agreements } \\
\text { Benefits of federal and state government to export }\end{array}$ \\
\hline $\begin{array}{l}\text { Products with new designs, keeping the } \\
\text { style of the Old West }\end{array}$ & Product design, sustainability and social responsibility, efficient production and quality \\
\hline Getting higher than expected profits & $\begin{array}{l}\text { Staff trained in production and sales } \\
\text { Value relationship with suppliers and logistics operators }\end{array}$ \\
\hline
\end{tabular}

Note. Source: Own elaboration. 


\section{Analysis of Critical Business Success Factors}

Rockart (1982) defined success factors such as the limited number of areas in which results, if they are satisfactory, will ensure successful competitive performance for the organization.

Table 1 above shows these factors that are shown as a summary of the main objectives and some strategies through which it is possible to achieve.

\section{Strategic Analysis of the Company}

SWOT (Strengths, Weaknesses, Opportunities, and Threats) analysis is an evaluation technique designed during the 70s by the American Albert Humphrey, a specialist in business management and cultural change. It involves an assessment of the strengths and weaknesses factors that together diagnose the internal situation of an organization and its external evaluation; that is, opportunities and threats (Talancón, 2006).

Table 2 shows the SWOT matrix for the case study at hand, and it is possible to see that for the internationalization strategy, the limited experience in the export process is a focus of alert for the company to reach international markets. Moreover, specialization in product type is a very significant advantage.

Table 2

SWOT Analysis of CC Company

\begin{tabular}{|c|c|c|c|}
\hline Strengths & Weaknesses & Opportunities & Threats \\
\hline $\begin{array}{l}\text { The raw material used for } \\
\text { the production of its goods is } \\
\text { fully national (Mexican). } \\
\text { It has the necessary capital for } \\
\text { large productions, and then } \\
\text { can support large exports, } \\
\text { which recovers the cost of } \\
\text { export. } \\
\text { It has well-structured } \\
\text { departments, therefore, it is } \\
\text { able to respond to an export } \\
\text { operation. } \\
\text { The product has quality against } \\
\text { the competition. } \\
\text { It has a license that allows the } \\
\text { use of a brand that is already } \\
\text { recognized in the market. }\end{array}$ & $\begin{array}{l}\text { Limited experience in exports. } \\
\text { Strong competition from } \\
\text { companies in the same line that } \\
\text { are already positioned in the } \\
\text { market for cowboy boots. } \\
\text { Dependence on suppliers, } \\
\text { especially leather. } \\
\text { Young company with little } \\
\text { experience in the market. }\end{array}$ & $\begin{array}{l}\text { Cover a market (cowboy boots) } \\
\text { that has not been potentiated by } \\
\text { another company in the same } \\
\text { style. } \\
\text { For export, the market has the } \\
\text { economic capacity to respond } \\
\text { to the product price. } \\
\text { The product price is } \\
\text { competitive with the rest of the } \\
\text { competition. } \\
\text { The product tariff (harmonized } \\
\text { code) has no export restrictions } \\
\text { with respect to the chosen } \\
\text { country. } \\
\text { International free trade } \\
\text { agreements. }\end{array}$ & $\begin{array}{l}\text { The provisions of the tariff } \\
\text { classification of the product } \\
\text { could be modified for some } \\
\text { decree; therefore, some export } \\
\text { restrictions might arise. } \\
\text { The Mexican peso could } \\
\text { depreciate further against the } \\
\text { dollar, leading to increased } \\
\text { production costs. } \\
\text { The import restrictions could } \\
\text { increase in the exporting } \\
\text { country, affecting the export of } \\
\text { the goods. }\end{array}$ \\
\hline
\end{tabular}

Note. Source: Own elaboration.

\section{Internationalization Strategies}

When a company is competitive in its domestic market, it likely will expand first in its domestic market and will only seek new opportunities in foreign markets when their growth opportunities diminish. Obviously, it is foreseeable that the company that wants to enter international markets finds barriers to accessing them; the question is whether such barriers may be even higher for family businesses (Fernández \& Nieto, 2005).

Under the World Trade Organization (2015), trade facilitation has expanded into the business of value chains and increasing specialization in production phases in which countries have comparative advantage positive effect. ProMéxico (2016) indicates that companies are international when they have a commercial or productive expansion in other countries. The Business Information System in the Canary Islands (SIECAN, 2016) defined the concept as the set of activities that the company develops outside markets that constitute their natural geographical environment. J. Wild, K. Wild, and Valladares Montemayor (2015, p. 4) indicated that 
international business is any commercial transaction that crosses the borders of two or more nations. This is also related to the globalization, that is, the trend toward greater economic, cultural, political, and technological interdependence among national institutions and economies. It is a comprehensive process that aims to incorporate an international dimension and perspective on the mission and vision, in the substantive functions of the institution, such as research and extension, so that it is a substantial part of their identity and political and institutional culture.

\section{Strategic Capacity of the Company for Internationalization}

Everything that could give us a competitive advantage could translate into consistent strategic value of the company. Having a clear and open agreement on these values will help establish meaningful priorities of the organization, its fields of endeavor, and levels of tolerance for deviations; allowing to set expectations and how to communicate them to others, what businesses to intervene in, and how to manage them (Morrisey, 1995).

There are different aspects that bring added value to the CC company as for example: fully national and good quality inputs, it has a strategic geographical position, as it is in the state of Guanajuato, in the city of Leon known as "the world capital of footwear" and uses an internationally recognized trademark license.

\section{Competition and Barriers to Entry}

According to the System Mexican Business Information (SIEM, 2016), 7,164 companies are registered in the footwear sector, while "The International Fair of Footwear and Leather Goods” for 2016 recorded 456 companies manufacturing footwear, of which 33 companies are engaged in the manufacture of cowboy boots (SAPICA, 2016).

Entry barriers were somewhat difficult to overcome, since the company has great competition. The market for cowboy boots is broad, and many companies looking to enter this market or looking to expand the same use or apply strategic alliances as franchising, licensing brand, among others, to access it way more simple. The use of these strategic alliances increases the likelihood that competition grows in any field, from the commissary and shoemaking. There is much competition in the market for cowboy boots, however, as we have discussed in previous forces, the company has advantages in all commercial aspects. Perhaps these advantages are not significant, but they are persistent, and together, this will allow the company to rival for its competitors: both companies that are well positioned, and those that are born as new competitors.

\section{Analysis of Export Potential}

The World Trade Organization (2016) suggested that trade capacity is the competitive ability of a person, organization, country, etc., to benefit from the system of multilateral trade efficiently so we can meet the international market needs. Harry and Schroeder (2000) pointed out that the product quality is to meet all the requirements of the activities to ensure the quality of the product design, once obtained, keeping it in other production and delivery to the customer. The export potential is then defined as the sum of the attributes that the company should have to deal with on the international market, in an environment where competition is the main obstacle to face and overcome.

Osorio (1987) defined production capacity as the ability to produce goods and services, typical of an organization that aims to generate income by resources not incorporated into production. Brosa (2007) described the management capacity and the potential of an economic manager to act effectively in the positive development of the business target. Based on the above, Table 3 indicates the operationalization of variables measuring the export potential of the company CC. 
Table 3

Operationalization of Variables

\begin{tabular}{|c|c|c|}
\hline Variables - ponderation & Item & Value \\
\hline \multirow{10}{*}{$\begin{array}{l}\text { Commercial capacity of the company } \\
28 / 10=2.8 \times 0.2=0.56\end{array}$} & 8 & 3 \\
\hline & 12 & 1 \\
\hline & 32 & 5 \\
\hline & 33 & 5 \\
\hline & 40 & 1 \\
\hline & 41 & 1 \\
\hline & 42 & 1 \\
\hline & 47 & 1 \\
\hline & 49 & 5 \\
\hline & 51 & 5 \\
\hline \multirow{11}{*}{$\begin{array}{l}\text { Product quality } \\
24 / 11=2.27 \times 0.40=0.908\end{array}$} & 14 & 1 \\
\hline & 15 & 1 \\
\hline & 16 & 1 \\
\hline & 17 & 1 \\
\hline & 18 & 4 \\
\hline & 19 & 4 \\
\hline & 20 & 5 \\
\hline & 21 & 5 \\
\hline & 22 & 1 \\
\hline & 23 & 1 \\
\hline & 24 & 1 \\
\hline \multirow{17}{*}{$\begin{array}{l}\text { Productive capacity } \\
68 / 17=4 \times 0.25=1\end{array}$} & 25 & 1 \\
\hline & 26 & 5 \\
\hline & 27 & 4 \\
\hline & 28 & 5 \\
\hline & 29 & 5 \\
\hline & 30 & 5 \\
\hline & 31 & 4 \\
\hline & 34 & 1 \\
\hline & 35 & 5 \\
\hline & 36 & 5 \\
\hline & 37 & 3 \\
\hline & 38 & 5 \\
\hline & 39 & 5 \\
\hline & 46 & 5 \\
\hline & 50 & 5 \\
\hline & 55 & 1 \\
\hline & 56 & 4 \\
\hline \multirow{7}{*}{$\begin{array}{l}\text { Company management capacity } \\
11 / 7=1.57 \times 0.15=0.2357\end{array}$} & 13 & 1 \\
\hline & 43 & 5 \\
\hline & 44 & 1 \\
\hline & 45 & 1 \\
\hline & 52 & 1 \\
\hline & 53 & 1 \\
\hline & 54 & 1 \\
\hline
\end{tabular}


Table 4

Results of the Company CC

\begin{tabular}{ll}
\hline Variables & Value \\
\hline Commercial capacity & 0.56 \\
Product quality & 0.90 \\
Productive capacity & 1.0 \\
Management capacity & 0.23 \\
\hline
\end{tabular}

Notes. Add the respective score for each question to get the average of each category. Multiply the average by the respective percentage of each section. Source: Own elaboration.

\section{Export Restrictions}

The permit or certificate of the Convention on International Trade in Endangered Species of Wild Fauna and Flora (CITES) is required in the case of parts and derivatives of wildlife species listed in the Appendices of CITES intended for customs procedures: permanent, temporary or tax deposit, or with the authorization of the Ministry of Environment and Natural Resources (SEMARNAT) in other cases and inspection of the Federal Office for the Environment (PROFEPA) in all cases. The documents are issued in terms of Item Nine and the inspection is performed in terms of the Eighth Point Agreement (Caaarem, 2016).

Cowboy boots correspond to the tariff harmonized code 64.03.51.01, which is not listed in the terms of the Ninth and Eighth Point Agreement SEMARNAT, based on the Agreement establishing the classification and codification of goods whose import and export is subject to regulation by the Secretariat of Environment and Natural Resources, published in the Official Journal of the Federation on December 19, 2012.

\section{Impact Management Restricted Substances for Products Leather-Shoes-Supply Chain}

On August 9, 2012, the Chamber of the Footwear Industry of the State of Mexico (CICEG) established as one of its strategic goals the conquest of markets and it seeks to position the Mexican footwear produced in Guanajuato in the global market.

Developed countries have established standards or regulations to export to these places and in this situation, the CICEG (2016) with the support of organizations such as the Center for Applied Innovation in Competitive Technologies (CIATEC) and the Coordinadora de Fomento al Comercio Exterior of the State of Guanajuato (COFOCE, 2016) (a decentralized institution of the Government of the State of Guanajuato that promotes the exports of local industries) was given the task of informing the business owners who supply to the leather footwear sector how to comply with this regulation.

Security Law for Consumer Products establishes rules for around 15,000 items and goods that are intended for children under 12 years, the purpose of this regulation is to increase safety in consumer products including footwear. Currently, several companies in the sector have made great efforts to comply with all regulations and their customers in this area of demand, however, it is required to consolidate the mechanisms for collaboration between the chain of suppliers and manufacturers to achieve joint efforts and facilitate compliance with these regulations. Governments, manufacturers, and retailers are increasingly concerned about health care, safety, and the impact of consumer products for which have been established a number of regulations aimed at eliminating hazardous substances such as lead, phthalates, chlorinated phenols, formaldehyde and dimethyl fumarate, which when contained in products can cause damage in the short, medium, or long term (CICEG, 2012), and these regulations are mainly in the countries of the US, Japan, China, and the European Community (Secretaría de Economía, 2014). 


\section{Logistics for Export}

Specifically for the export to North America, the international packing and packaging is specified. Each pair of boots will be contained in its own box and each box of boots will be placed in a larger box. The box containing the pairs of boots has a dimension of $70 \mathrm{~cm}$ high, $100 \mathrm{~cm}$ wide and $120 \mathrm{~cm}$ long. In each case, fit a maximum of 38 boxes of Knight boots, therefore, 12 large boxes are required to contain 400 pairs (for men's sizes). On each pallet, three large boxes, one will be placed as a base and stacked on top, for this export packaging, the total capacity is 4 pallets. The measures of the pallet with stacked boxes are $100 \mathrm{~cm}$ wide $\times 120$ $\mathrm{cm}$ long $\times 230 \mathrm{~cm}$ high, which is to use a container trailer. Finally, to export the 400 pairs of boots, only a consolidated container service trailer (LTL) will be required.

\section{Results}

\section{Strategic Value of Business}

The fact that the company is young does not mean it will not have competitive advantages or even having been in the market for a longer time will have more advantages, but the company should seek to be different from the start and during development. From what we observed, it does not have many differences compared to the competition, however, but the ones it does have should be fully exploited and even with only those advantages it could do more than other companies. Success will be in the proper use of its advantages through strategies, and this requires good planning and good use of its resources.

For analysis of the competitive advantage of the product, considering Porter's (1985) five forces, we can see that although it is a company that only manufactures its products for its parent, the sector it belongs to gives advantages automatically, since it is a potential sector in the country, in addition to the characteristics of geographical position, broad portfolio of suppliers and a foreign customer who likes those products. Therefore, the use of them allows the company a continuous and successful growth.

\section{Analysis of Export Potential}

Commercial capacity of the company. The company is responsive to sales abroad, i.e., with time it may condition its processes for productions requested and can also offer their customers the quality they want for the product.

Product quality. It is seen to have a little disadvantage in the field of use of international trade, but that does not make it bad, it just tells us that it has not joined the international market, therefore causing a low rating.

Company and its productive capacity. The company has trained staff to respond to exports or imports inclusive. All departments are connected and synchronized to carry out the functions, from purchasing materials to finished products sales staff. It is a company that has vision, since it prepared itself with a foreign trade department starting soon for its first foreign sales.

Management capacity. Management capacity is weak, but not because they do not have a good structure in the company, or that it does not have the trained personnel to perform the functions, but the result just shows that the company is young, and therefore, it is new to the ways of export and import.

Finally, we can conclude about the results of the questionnaire designed to measure export potential, the company is suitable for export and undoubtedly will succeed in the international trading arena. It is expected that over time, the company will maintain its quality principles of its work, and thus it can be a company with the potential of export, and also an innovation in its production and administrative processes to remain in the market. 


\section{Analysis of Critical Factors for Success}

The company has many resources that can exploit and make the most of to meet their objectives described above. Money is the resource that will have to be invested first, for both production costs and staff hired or recruited in the future to achieve its objectives and achieve its mission and vision.

Then, once the company complies with the process described above, time will be its second appeal, as they will already have determined how much effort should be applied to exploit every opportunity they can find in its external work environment. That is, be aware of training fairs, financial support, etc., as we know, these events have specific dates, resources which must be acquired and kept to make it easier to achieve the goals that have been proposed.

\section{SWOT Analysis}

In every company, threats or opportunities will arise, the key is that companies know to take advantage and make the most of the situation. We believe that the company CC is internally suitable for export quality; however, it is essential that the company is constantly updated to respond to any sudden change in the economy, market, etc.. Also, it should be noted that these changes can only be met if you have plans to do so. For this reason, the company must adopt a culture of constant planning.

\section{Conclusion}

For the footwear market, both designs, quality, durability, and comfort are important elements for customers. To replace CC boots, the company needs to adapt the design of the boots. Each company has a style and design, which leads to customer loyalty towards companies. In addition, the company uses a brand that is already positioned internationally, giving it an advantage over companies not yet recognized in the market for cowboy boots. While the company continues with the quality standards that apply to its products, you can avoid a certain percentage to surpass products such as synthetic leather boots.

Although CC is a company that only manufactures the product and then returns the product to its headquarters, it has managed to exceed the average life time of small and medium enterprises in Mexico, which is two years.

Based on the results of research and analysis of company data, we can say that the company is suitable to break into foreign markets. It is important that, as a result of these positive results, the company does not rush, but, as already indicated, the company adopts a culture of formal type planning, and not only that, but also continues evaluation and monitoring of the strategies and activities it applies.

The company also plans to be taken serious and in a formal way to further minimize the risks arising from export. This is essential, since the analysis will be able to reduce the uncertainty of export costs, knowledge of support programs, trade benefits, etc..

Seizing the opportunities that the environment offers the company, it is a key point to succeed in the objectives. It is definitely not easy to carry out an internationalization project, not only due to the time that is spent, but also because that the money is often not their own, which therefore brings even greater responsibilities. Also, such a project without knowledge of the matter could not be carried out, as there would be no key details that impact the internationalization plan, such as knowledge of laws that protect the project, government programs, and regulatory agencies of international trade. 


\section{References}

Arredondo, M. G., \& Caldera, D. (2016). La inserción en mercados internacionales a partir de la sucesión de la administración de una PyME familiar mexicana. Przedsiębiorczość i Zarzqdzanie, 17(6), 131-143.

Brosa, S. (2007). La capacidad gerencial. Siglo XXI. Retrieved from http://www.diariosigloxxi.com/texto-diario/mostrar/21150/la-capacidad-gerencial

Business Information System in the Canary Islands [SIECAN]. (2016). Definición de internacionalización. Sistema de Información Empresarial en Canarias (SIECAN). Retrieved from http://www.siecan.org/index.php?option=com_content\&view=article\&id=360:internacionalizacion\&Itemid=120\&lang=es

Caaarem. (2016). Tarifa de la Ley General de Impuestos a la Importación y la Exportación. Retrieved from http://www.siicex-caaarem.org.mx/

CICEG. (2012). Impacto de las sustancias restringidas. Cámara de la Industria del Calzado del Estado de Guanajuato. Retrieved from http://www.ciceg.org/boletines/09agosto2012.pdf

CICEG. (2016). Directorio de miembros de SAPICA. Retrieved from http://www.ciceg.org/sapica/marzo16/directorio_sapmar16.pdf

COFOCE. (2016). Llenado de documentos para la exportación. Retrieved from http://www.cofoce.gob.mx/es/para-exportadores/servicios-a-la exportacion/informacion-en-comercio-exterior/detalle1/534

Fernández, Z., \& Nieto, M. J. (2005). La estrategia de internacionalización de la pequeña empresa familiar. Madrid, España: Cuadernos de Economía y Dirección de la Empresa.

Harry, M., \& Schroeder, R. (2000). Six sigma: The breakthrough management strategy revolutionizing the world's top corporations. New York, NY: Doubleday.

Morrisey, G. L. (1995). Pensamiento Estratégico. Construyendo los Cimientos de la Planeación. Estados Unidos, Florida: Prentice Hall.

Osorio, O. (1987). La capacidad de producción y los costos. Buenos Aires, Argentina: Ediciones Macchi.

Porter, M. (1985). Ventaja competitiva: “Creación y sostenimiento de un desempeño superior”. Cambridge: Pirámide.

ProMéxico. (2016). Definición de Internacionalización. $\quad$ Retrieved from http://www.promexico.gob.mx/es/mx/definicion-de-internacionalizacion

Rockart, J. F. (1982). The changing role of the information systems executive: A critical success factors perspective. In J. F. Rockart (Ed.), The changing role of the information systems executive (pp. 3-13). New York, NY: Sloan Management Review Fall.

SAPICA. (2016). Exporters directory. Guanajuato, México: Cámara de la Industria del Calzado.

Secretaría de Economía. (2014). El TLCAN posicionó a México como un socio comercial estratégico para Canadá. Retrieved from http://economia.gob.mx/files/importancia_del_tlcan_para_la_relacion_mexico_canada.pdf

Secretaría de Economía. (2015). La Industria del Calzado en México. Retrieved from http://www.gob.mx/se/articulos/la-industria-del-calzado-en-mexico

System Mexican Business Information [SIEM]. (2016). Estadisticas de PyMES. Sistema de Información Empresarial Mexicano (SIEM). Retrieved from http://www.siem.gob.mx/siem/

Talancón, H. P. (2006). La matriz FODA: una alternativa para realizar diagnósticos y determinar estrategias de intervención en las organizaciones productivas y sociales. Retrieved from http://www.eumed.net/ce/2006/hpt-FODA.htm

Wild, J., Wild, K., \& Valladares Montemayor, H. (2015). International business: The challenges of globalization. Toronto, Canada: Pearson.

World Trade Organization. (2015). Informe sobre el Comercio Mundial 2015. Retrieved from https://www.wto.org/spanish/res_s/booksp_s/world_trade_report15_s.pdf

World Trade Organization. (2016). Informe sobre el Comercio Mundial 2016. Igualdad de condiciones para el comercio de las PyMes. 